\title{
Modeling of Infiltration Wells to Reduce Rainwater Runoff of Buildings: A Case Study in Campus of Polytechnic State of Sriwijaya, Indonesia
}

\author{
Radius Pranoto ${ }^{1, *}$ Anggi Nidya $S^{1}$ Ricky RA ${ }^{1}$ Djaka Suhirkam ${ }^{1}$ Viktor Suryan ${ }^{2}$ \\ ${ }^{1}$ Civil Department, Polytechnic State of Sriwijaya, Palembang 30139, Indonesia \\ ${ }^{2}$ Civil Department, Palembang Aviation Polytechnic, Palembang 30139, Indonesia \\ *Corresponding author. Email: radius.pranoto@polsri.ac.id
}

\begin{abstract}
Rainfall in Indonesia is classified as high, indicated by the average which ranges from 2000-4000 mm/year. This potential, on the other hand, often creates problems as a result of rain falling to the surface which usually only becomes surface runoff, inundation, and flooding. Infiltration wells are rainwater conservation technologies that have been widely applied to reduce surface runoff and at the same time increase groundwater reserves. The case study was conducted at the Sriwijaya State Polytechnic Campus, Indonesia. The purpose of this study was to determine the model of infiltration wells for controlling rainwater runoff which is suitable to be applied in the research area. Based on field testing using a doublering infiltrometer, the infiltration capacity value obtained was $3.42 \mathrm{~cm} /$ hour. The infiltration well model used in this case is a cylindrical type of impermeable wall, with a diameter of $1-1.4 \mathrm{~m}$ and a depth of $1.5-2.5 \mathrm{~m}$. The simulation was carried out per $100 \mathrm{~m}^{2}$ rainfed area (roof of the building) for one infiltration well by referring to daily rainfall data for 12 years (2007-2018). The simulation results show that infiltration wells with a diameter (1.2 - $1.4 \mathrm{~m})$ and depth (2.5 m) were able to reduce rainwater runoff by $68.3 \%$ and occurred 1163 times overflow for 12 years. The simulation also revealed that increasing the diameter was more effective in increasing the amount of rainwater runoff reduced than increasing the depth of the infiltration well.
\end{abstract}

Keywords: rainfall, surface runoff, infiltration wells, double ring infiltrometer

\section{INTRODUCTION}

The Sriwijaya State Polytechnic Campus stands on an area of approximately 7.2 hectares with buildings covering an area of 2.6 hectares. Currently, Sriwijaya State Polytechnic Campus does not yet have a self-sufficient source of clean water so that all clean water needs are supplied from the Regional Drinking Water Company (PDAM) of Palembang City. It is known that drilling for artesian wells has been carried out several times, but potential aquifers have not been found. Efforts to conservation rainwater that can be used as an alternative source of clean water in the campus environment have unfortunately not been carried out. Rain that flows in the form of runoff discharge from built-up land and yards is all discharged through drainage channels. According to [1] Palembang City has a fairly high rainfall, so there are often puddles in several places when it rains. Furthermore, [2] said that, rainfall if not managed properly will harm the environment, such as; runoff, flooding, and erosion or loss off nutrients [3], [4]. On the other hand, rainwater can be conserved to increase reserves or as water storage in the dry season [5], [6], [7], [8], [9], [10].

In recent years, rainwater management through infiltration well technology has been widely carried out as an environmentally sound water conservation effort [11], especially in densely built areas. Infiltration wells have proven to be effective in reducing surface runoff, reducing flooding, and increasing groundwater reserves [12]. The concept of infiltration wells is to absorb rain runoff as much as possible into the ground so that the water coming out of a catchment area is minimal or even zero.

The application of infiltration well technology in the Sriwijaya State Polytechnic Campus has its challenges because the natural condition of the soil structure is dominated by a backfill with a silt texture (clay and fine sand). This condition is predicted to cause the ability of the soil to absorb water to be low. In addition, the condition of the groundwater level at a location that has a depth of about 3 meters will be a limitation that the planned infiltration well is shallow. This research is the first step in determining the most suitable infiltration well model to 
control rain runoff from building parcels in the Sriwijaya State Polytechnic Campus. Palembang City has an average daily rainfall of around $14.91 \mathrm{~mm}$ with a total of 179 rainy days per year.

\section{RESEARCH METHODOLOGY}

\subsection{Research Area}

The research took place at the Sriwijaya State Polytechnic Campus, which is located on Jalan Srijaya Negara, Bukit Lama, Bukit Besar, Palembang City, South Sumatra, Indonesia.

\subsection{Tools and Data}

The tools used in this study were a double-ring infiltrometer (30 cm high, small ring diameter $15 \mathrm{~cm}$, and large ring diameter $30 \mathrm{~cm}$ ), measuring instrument (meter), and a set of laptops with MS.Office applications, Arc-GIS 10.0, Auto-CAD 2010, and Google Earth. The research data consists of infiltration rate data from measurements, daily rainfall data for the 2007-2018 period obtained from the BMKG (Meteorology, Climatology and Geophysics Agency of Kenten Palembang), and data on the area of the building of the Sriwijaya State Polytechnic campus.

\subsection{Research Stages}

\subsubsection{Infiltration Rate Measurement}

Infiltration rate measurement refers to SNI-7752-2012 concerning Procedures for Infiltration Rate Measurement [13]. The infiltration rate was measured using a doublering infiltrometer at 3 (three) points spread over the study site. The measurement begins with making a hole in the ground with a length of $1.5 \mathrm{~m}$, a width of $1 \mathrm{~m}$, and a depth of $0.5 \mathrm{~m}$. After that, the double-ring infiltrometer was planted vertically as deep as $10-15 \mathrm{~cm}$ in the prepared hole to then be filled with water until it was full and the duration of the water decrease was observed. Tests and measurements were carried out until a constant infiltration rate was obtained. Infiltration capacity $\left(f_{c}\right)$ is calculated based on data on changes in water level when the infiltration rate has reached a constant. The equation used refers to [13]:

fc $=\left[\frac{\Delta h_{c}}{\Delta t}\right] \times 60$

where:

$\mathrm{f}_{\mathrm{c}} \quad=$ infiltration capacity ( $\mathrm{cm} /$ hour)

$\Delta h_{c} \quad=$ change in water level per time interval $(\mathrm{cm})$

$\Delta t \quad=$ measurement time interval (minutes)
The value of infiltration capacity (in meters/day) is obtained from the $f_{c}$ value in Equation (1) multiplied by the conversion value as follows:

$\mathrm{f}_{\mathrm{c}(\mathrm{m} / \text { day })}=\mathrm{f}_{\mathrm{c}(\mathrm{cm} / \text { hour })} \times \frac{24}{100}$

\subsubsection{Building Plot Area Measurement}

Data related to the area of building parcels $\left(\mathrm{m}^{2}\right)$ measured in this study are the main buildings which include administrative buildings, educational buildings, lecture halls, laboratories, workshop buildings, and mosques. The area of the parcels is measured directly using a measuring tape.

\subsubsection{Input Discharge Calculation}

The input discharge to be entered into the infiltration well comes from the rainfall that overflows from the rainfed area (the roof of the building). The amount of input discharge is calculated based on daily rainfall and refers to equition [13] as follows.

$\mathrm{Q}_{\mathrm{t}}=0.855 \times \mathrm{C} \times \mathrm{R} \times \mathrm{A}$

where:

$Q_{t}=$ Infiltration well input discharge $\left(\mathrm{m}^{3} /\right.$ day)

$\mathrm{C}=$ Coefficient of runoff on building parcels

$\mathrm{R}$ = daily rainfall $(\mathrm{m} / \mathrm{hari})$

$\mathrm{A}=$ Rainfed area $\left(\mathrm{m}^{2}\right)$

\subsubsection{Analysis and Simulation Modeling}

The planned infiltration well model refers to the Regulation of The Minister of Public Works no. 11/PRT/M/2014 concerning Rainwater Management in Buildings and Their Parcels [14], as well as guided by SNI 03-2453-2002 concerning Technical Planning Procedures for Rainwater Infiltration Wells for Yard Land [15].

The purpose of a model simulation is to predict daily water fluctuations that occur in infiltration wells. The predicted parameters are the amount of incoming water (input discharge), changes in water level, the amount of water accommodated, the amount of water seepage, and the amount of water overflowing from the infiltration well. All parameter values are converted into units for height (m). The mathematical model used to predict the event is Equation (4) as follows.

$$
\begin{aligned}
& \Delta \mathrm{H}_{\mathrm{t}}=\mathrm{H}_{(\mathrm{t}-1)}+\mathrm{H}_{\mathrm{t}}-\mathrm{f}_{\mathrm{c}}-\mathrm{O}_{\mathrm{f}} \\
& \mathrm{H}_{\mathrm{t}}=\frac{4 Q_{t}}{\pi \cdot d^{2}} \\
& \text { where: } \\
& \Delta \mathrm{H}_{\mathrm{t}}=\text { Changes in water level in infiltration wells } \\
& \text { (m/day) } \\
& \mathrm{H}_{(\mathrm{t}-1)}=\text { Amount of residual water from the previous } \\
& \text { day ( } \mathrm{m} / \text { day) } \\
& \mathrm{H}_{\mathrm{t}} \quad=\text { Height of input debit from the building } \\
& \text { parcel area (m) } \\
& \mathrm{f}_{\mathrm{c}} \quad=\text { Infiltration capacity of infiltration well (m/day) } \\
& \mathrm{O}_{\mathrm{f}} \quad=\text { Amount of water overflowing from } \\
& \text { infiltration well (m) }
\end{aligned}
$$


$\pi \quad=$ constant: 3.14

$\mathrm{d}=$ Diameter of infiltration well $(\mathrm{m})$

The amount of rainwater runoff that can be controlled (Qs) through infiltration wells (in \%) is predicted by Equation 6 as follows.

$\mathrm{Q}_{\mathrm{s}}=\frac{H_{t}-O_{f}}{H_{t}} \mathrm{X} 100 \%$

\section{RESULT AND DISCUSSION}

\subsection{Infiltration Rate}

The soil texture at the research site is generally dominated by silt (grains between clay and fine sand). Measurement of the infiltration rate was carried out at locations $(1,2$, and 3$)$ as shown in the Figure 1 and Figure 2. Soil conditions at the 3 (three) locations at the time of measurement were not much different, except at Location 2 where a faster infiltration rate was found. This is presumably because the soil at Location 2 has a higher fine-sand fraction with more organic content from leaf litter [16], [17], [18]. Moreover, this location is often used as a student practicum location for mixing sand (coarse material), excavating, and backfilling repeatedly so that the soil structure becomes loose and the soil porosity is higher. In contrast, [19], [20], stated that the low infiltration rate in disturbed soils usually occurs due to compaction of the soil structure due to other object activities and conversion into urban land uses [21], [22].

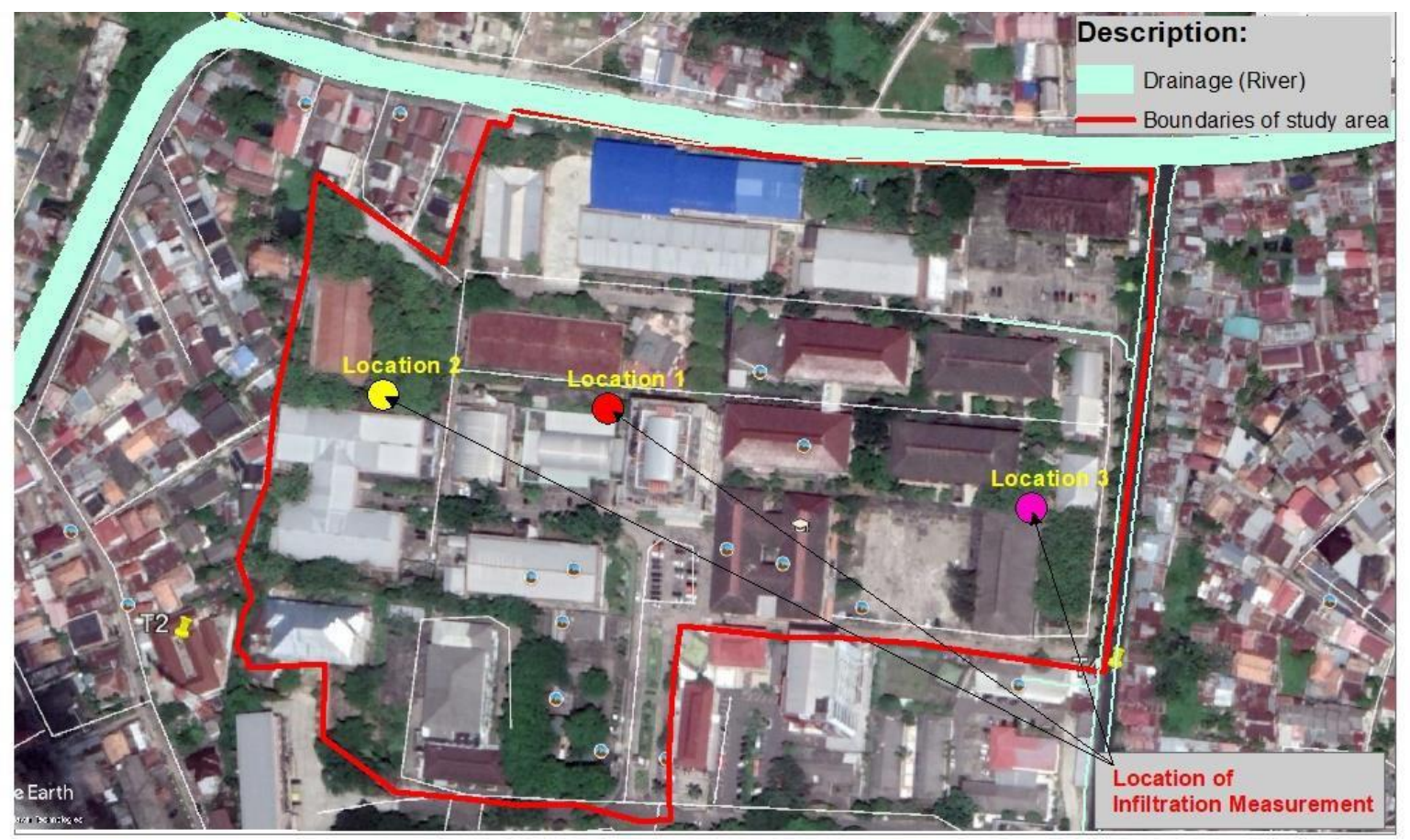

Figure 1. Locations of infiltration rate measurement

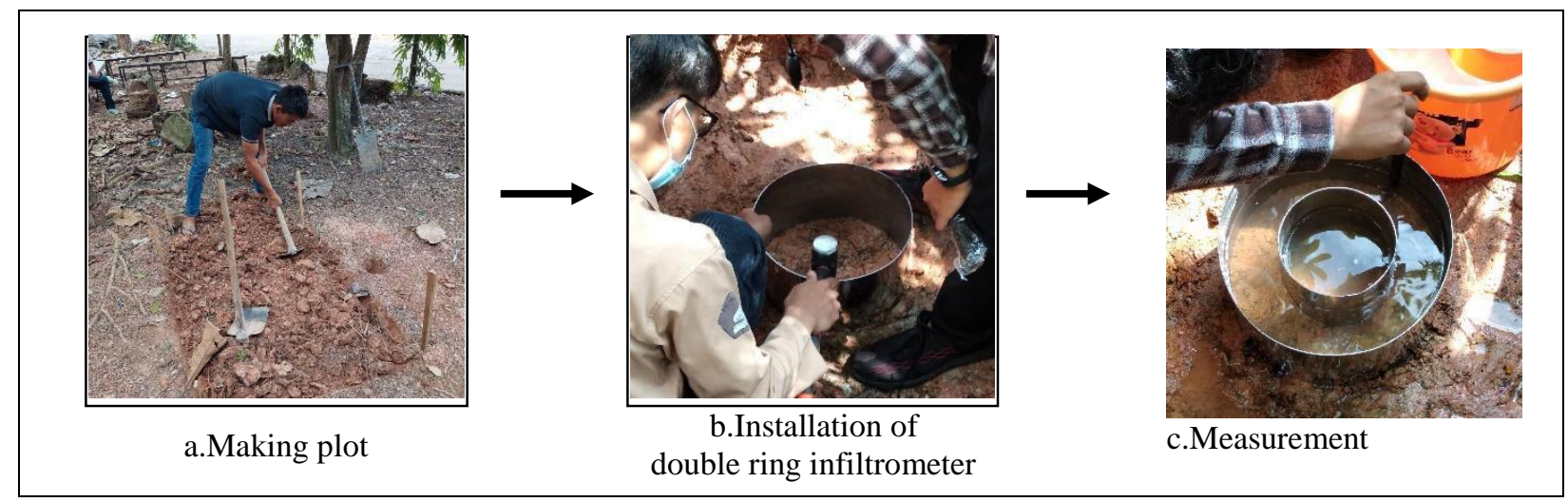

Figure 2. Infiltration rate measuremnt 
From the results of field measurements, the infiltration capacity values at locations 1,2 , and 3 obtained were (1.26 $\mathrm{cm} /$ hour $),(6.6 \mathrm{~cm} /$ hour $)$, and $(2.4 \mathrm{~cm} /$ hour $)$, respectively. The infiltration rate of the infiltration well is calculated from the average value of the infiltration capacity which is the result of the measurements of the three locations so that the value is $3.42 \mathrm{~cm} /$ hour or about $0.821 \mathrm{~m} /$ day. Based on the classification [23], the infiltration rate at the study site is categorized as low $(2.0-6.5 \mathrm{~cm} /$ hour$)$.

\subsection{Rain Runoff and Input Discharge}

Rain runoff occurs when the rain that falls on the surface cannot seep into the soil or the layers below it.
Surface runoff is influenced by the type of land uses [24], [25], [26] and rainfall patterns or intensity [27], [28]. Buildings account for the largest rainfall runoff. This is because the runoff coefficient value is greater than that of vegetated land or bare land [29]. The runoff coefficient (C) used in this study refers to the Regulation of the Minister of Public Works Number 12/PRT/M/2014 concerning the Implementation of the Urban Drainage System, which is 0.95 for the catchment area in the form of building parcels or building roofs. Figure 3 is the distribution of the roofs of the priority building as rainfed areas at the study site.

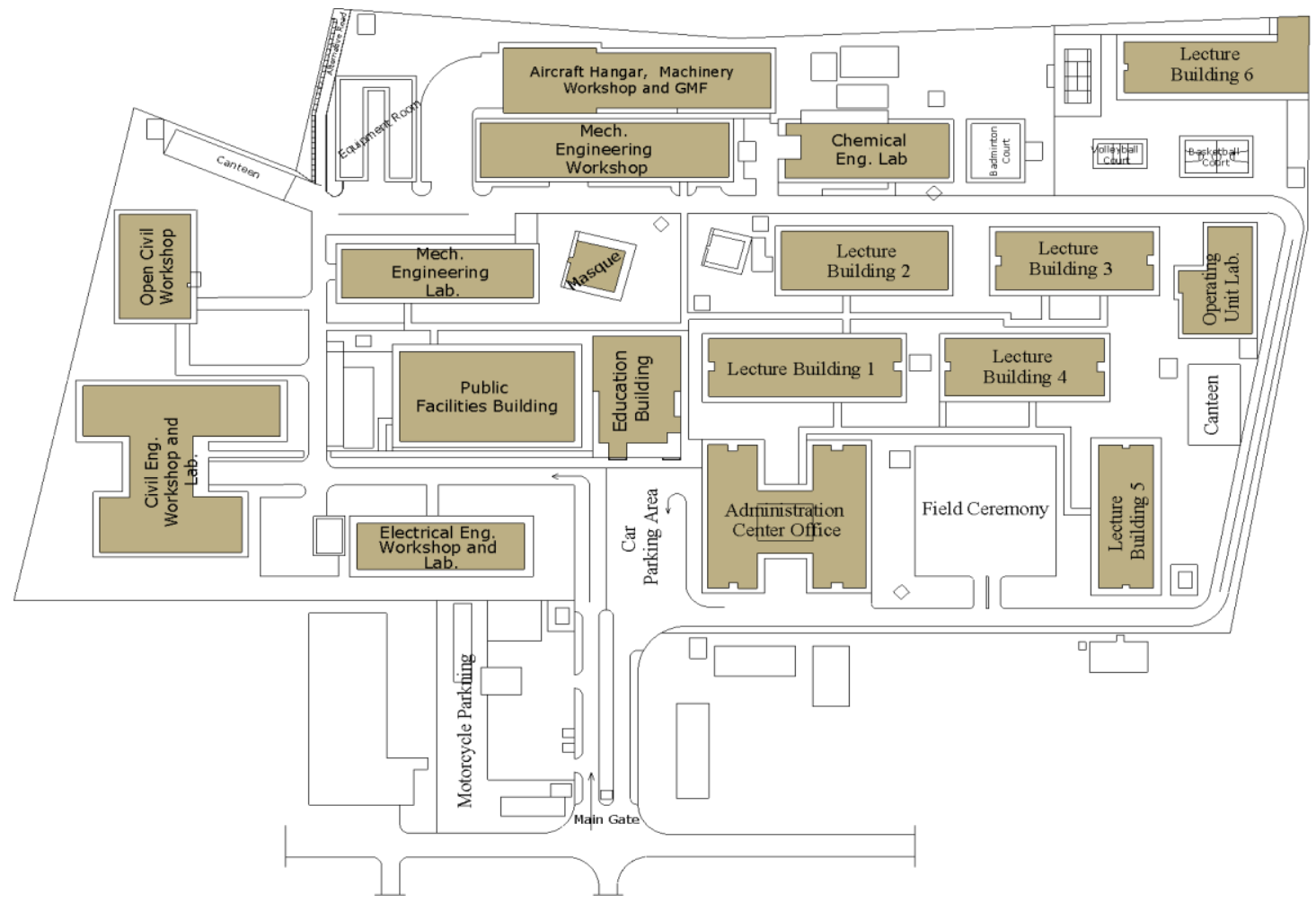

Figure 3. Distribution of building as rainfed areas at the study site

The runoff discharge $(\mathrm{Qt})$ is calculated by referring to Equation 3. The amount of daily runoff depends on the amount of rainfall. In this case, high rainfall will make the rain runoff also greater. The rainfall used in this study is daily rainfall for 12 years (2007-2018) obtained from the nearest rain station to the research location. In 12 years or about 4383 days, it is known that there were 2146 rainy days with an average daily rain value of $14.91 \mathrm{~mm} /$ day. Figure 4 shows the daily rainfall $(\mathrm{R})$ and the total runoff discharge $(\mathrm{Qt})$ originating from the rainfed surface (the roof of the building covering an area of $26,177 \mathrm{~m}^{2}$.

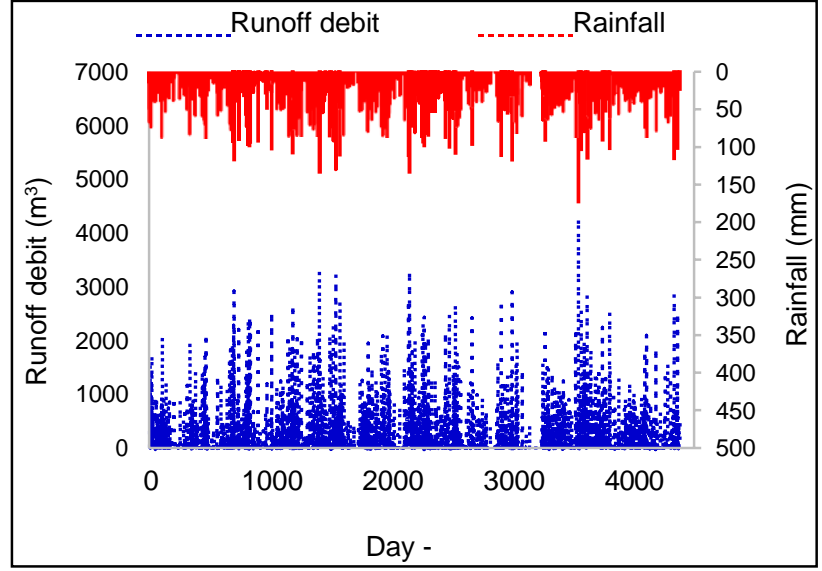

Figure 4. Graph of daily rainfall and runoff discharge 


\subsection{Modeling Simulation and Analysis}

The infiltration well model used in this study is a circular cross-section, impermeable wall (infiltration occurs vertically), with a diameter of $1-1.4 \mathrm{~m}$ and a depth of $1.5-2.5 \mathrm{~m}$. Determination of the depth is based on the condition of the groundwater table at the study site which ranges from 3-4 m. The input discharge entered into the infiltration well is rain runoff $(\mathrm{Qt})$ from the surface of the cistern (the roof area of the building). The input discharge is calculated in the form of input discharge height $(\mathrm{Ht})$ and simulated per $100 \mathrm{~m}^{2}$ of rainfed area (1 infiltration well per $100 \mathrm{~m}^{2}$ of rainfed area).

The model approach is predicted by Equation 4 and 5 . The assumption used is that when the first infiltration well is operated, the water level of the infiltration well is zero meters (empty well). For the next day, the infiltration well has a water level from the input discharge of rain runoff minus the amount of water that seeps in ( $\mathrm{fc}=0.821 \mathrm{~m} /$ day) and added the remaining water discharge on the previous day (Ht-1). Figure 5 illustrates the condition of an infiltration well when it receives runoff $(\mathrm{Ht})$, infiltration (fc), and overflow (Of) discharges.

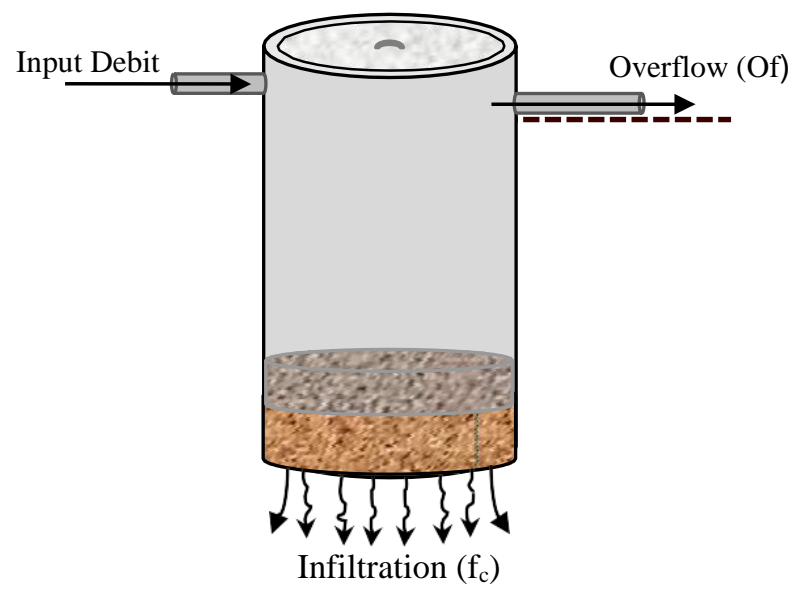

Figure 5. Simulation scheme of infiltration wells

When it rains, the runoff discharge $(\mathrm{Ht})$ from the roof of the building will enter the infiltration well. If the incoming runoff discharge is greater than the holding capacity and the infiltration capacity of the infiltration well, overflow will occur. On the other hand, if the incoming runoff discharge is less than the capacity, then the water level in the infiltration well is equal to the runoff discharge minus the infiltration capacity. However, if the incoming runoff discharge is smaller than the infiltration capacity, the infiltration well will dry up after all the water has been absorbed.

The graphs in Figure 6, 7, 8, and 9 provide information on fluctuations and yields of water in several models of infiltration wells. The results obtained showed that there was overflow ( $\geq 4238$ times) of a total of 4383 days (12 years) in infiltration wells with a diameter $(0.8-1 \mathrm{~m})$ and a depth of 2.5 with a tendency to increase.

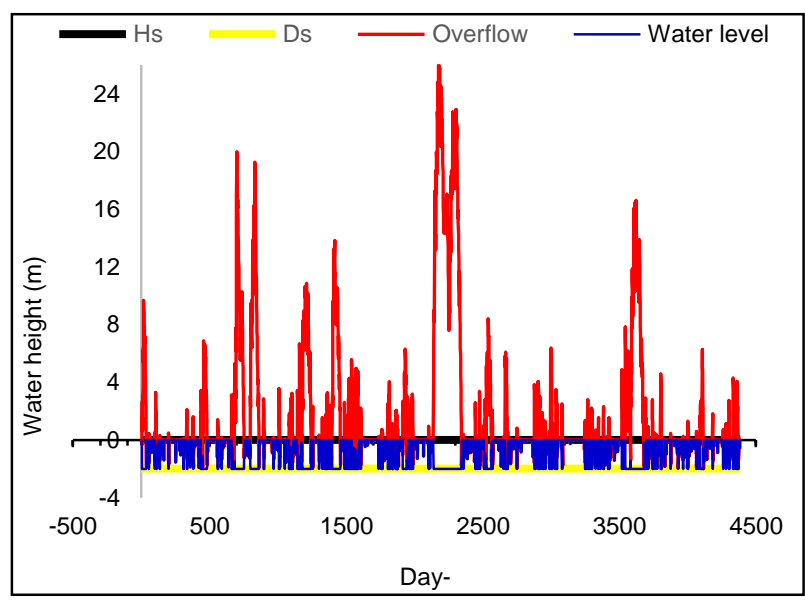

Figure 6. Water fluctuations in infiltration wells (depth $2 \mathrm{~m}$ and diameter 1,4 $\mathrm{m}$ )

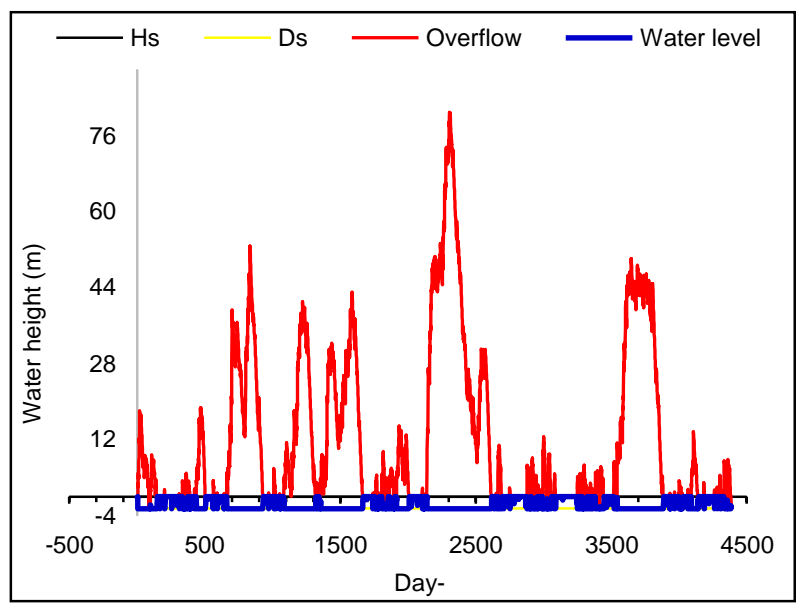

Figure 7. Water fluctuations in infiltration wells (depth 2,5 $\mathrm{m}$ and diameter 1,2 $\mathrm{m}$ )

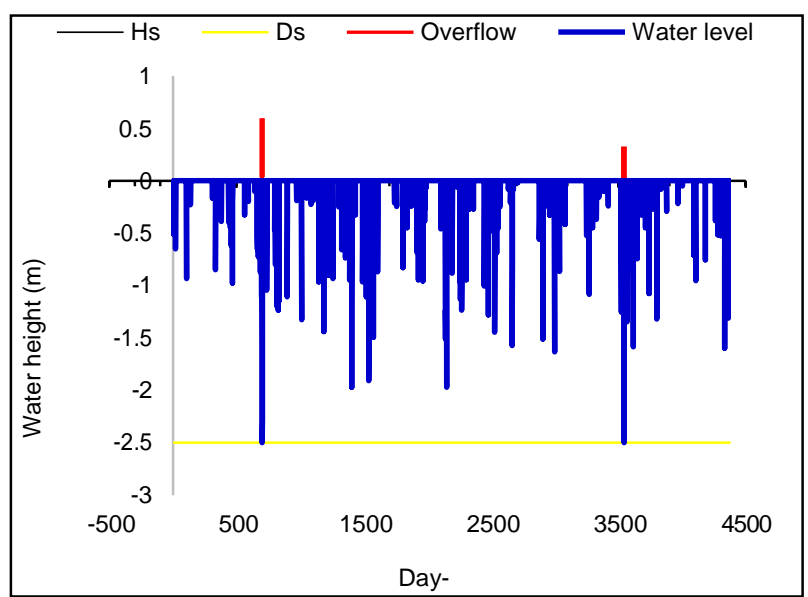

Figure 8. Water fluctuations in infiltration wells (depth 2,5 $\mathrm{m}$ and diameter 2,4 m) 


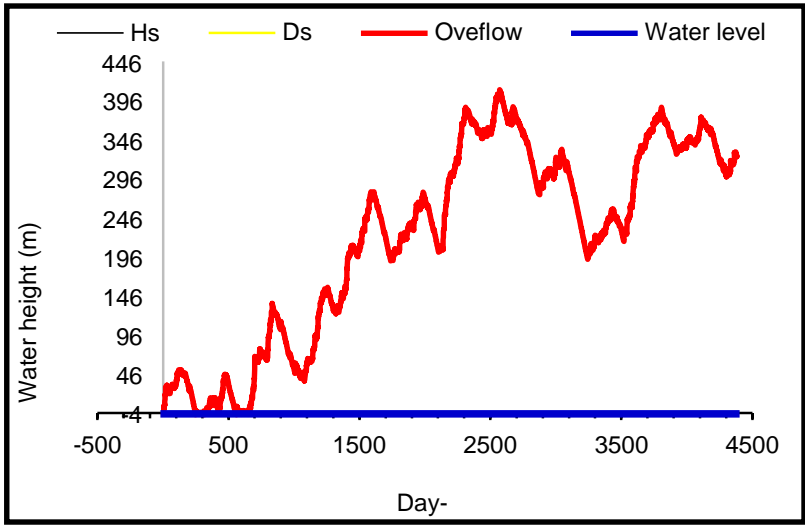

Figure 9. Water fluctuations in infiltration wells(depth $2,5 \mathrm{~m}$ and diameter $1 \mathrm{~m}$ )
The amount of overflowing water is much reduced in infiltration wells with a diameter of $1.4 \mathrm{~m}$ and a depth (1 $2.5 \mathrm{~m}$ ) with the least amount being 1163 times. If the diameter of the infiltration well is enlarged to $2.4 \mathrm{~m}$ and a maximum depth of $2.5 \mathrm{~m}$ is made, then the water yield will change significantly where it only overflows 3 times in a span of 12 years (2007-2018). The results of water in infiltration wells in detail are presented in Table 1.

Table 1. The yield of water in infiltration wells per $100 \mathrm{~m}^{2}$ of watershed area

\begin{tabular}{|c|c|c|c|c|c|c|c|c|}
\hline \multicolumn{2}{|c|}{$\begin{array}{l}\text { Water condition in the } \\
\text { infiltration wells (days) }\end{array}$} & $\mathrm{d}=2,4 \mathrm{~m}$ & $\mathrm{~d}=1,6 \mathrm{~m}$ & $\mathrm{~d}=1,4 \mathrm{~m}$ & $\mathrm{~d}=1,3 \mathrm{~m}$ & $\mathrm{~d}=1,2 \mathrm{~m}$ & $d=1$ & $\mathrm{~d}=0,8$ \\
\hline Over flow & \multirow{3}{*}{$\mathrm{h}=1,5 \mathrm{~m}$} & 16 & 679 & 1430 & 2011 & 2754 & 4259 & 4381 \\
\hline Filled & & 280 & 719 & 659 & 533 & 364 & 38 & 1 \\
\hline Dry & & 4087 & 2985 & 2294 & 1839 & 1265 & 86 & 2 \\
\hline Over flow & \multirow{3}{*}{$\mathrm{h}=2 \mathrm{~m}$} & 4 & 537 & 1288 & 1870 & 2658 & 4249 & 4380 \\
\hline Filled & & 292 & 861 & 801 & 674 & 460 & 48 & 2 \\
\hline Dry & & 4087 & 2985 & 2294 & 1839 & 1265 & 86 & 3 \\
\hline Over flow & \multirow{4}{*}{$\mathrm{h}=2,5 \mathrm{~m}$} & 3 & 425 & 1163 & 1766 & 2566 & 4238 & 4379 \\
\hline Filled & & 293 & 973 & 926 & 778 & 552 & 59 & 3 \\
\hline Dry & & 4087 & 2985 & 2294 & 1839 & 1265 & 86 & 1 \\
\hline & & & & & & & & \\
\hline
\end{tabular}

d: diameter, $h$ : depth of infiltration well)

\subsection{Infiltration Well Effectiveness}

The amount of rain runoff and inflitration that can be controlled indicates the efficiency level of the infiltration well. The effectiveness of infiltration wells is calculated based on the balance between the flow of water that enters and seeps into the ground [30]. In line with [31], from the simulation test proved that the infiltration systems such as; infiltration well or pond, and seepage weel performed a higher average infiltration rate and reduced total runoff, and according to [32], [33], improved water quality and recharged groundwater.

The simulation results show that infiltration wells with a diameter of $0.8-1 \mathrm{~m}$ and a depth of $1.5-2.5 \mathrm{~m}$ are only able to control the maximum rain runoff of $4.7 \%$. Meanwhile, infiltration wells with a diameter of $1.2-1.4$ $\mathrm{m}$ and a depth of $2.5 \mathrm{~m}$ can control a maximum runoff of $68.3 \%$ for every $100 \mathrm{~m} 2$ of rainfed area. Knowing this result, the total number of units of infiltration wells needed to reduce a maximum of $68.3 \%$ of rain runoff from the roof is 262 units. If the amount of water to be controlled reaches $100 \%$, the diameter of the infiltration well must be increased to $2.4 \mathrm{~m}$. However, this measure cannot be applied because the determination of the dimensions of rainwater infiltration wells is based on the Regulation Of The Minister Of Public Works no. 11/PRT/M/2014 is a maximum of $1.4 \mathrm{~m}$ in diameter. It is known from the simulations that increasing the diameter is more effective in increasing the amount of runoff to be controlled than increasing the depth of the infiltration well. The amount of rain runoff that is controlled for each infiltration well is presented in Table 2.

The infiltration well model chosen in this study is 1.4 $\mathrm{m}$ in diameter and $1.5-2.5 \mathrm{~m}$ deep as well of this size has the highest effectiveness in reducing rain runoff. However, in its application in the field, the current condition of the surrounding environment will also be considered. Moreover, the application of infiltration wells must meet the technical requirements of SNI 03-2453-2002, such as; the minimum groundwater depth is $1.5 \mathrm{~m}$ in the rainy season, the minimum distance to clean water wells is at least $3 \mathrm{~m}$, the minimum distance from the building foundation well is at least $1 \mathrm{~m}$, and the minimum distance to the septic tank is at least $5 \mathrm{~m}$. 
Table 2. Amount of controlled rain runoff per $100 \mathrm{~m}^{2}$ of rainfed area

\begin{tabular}{|c|c|c|c|c|c|c|c|}
\hline \multicolumn{7}{|c|}{ The percentage of water controlled } \\
\hline $\begin{array}{c}\text { Depth } \\
(\mathrm{h})\end{array}$ & $\mathrm{d}=2,4 \mathrm{~m}$ & $\mathrm{~d}=1,6 \mathrm{~m}$ & $\mathrm{~d}=1,4 \mathrm{~m}$ & $\mathrm{~d}=1,3 \mathrm{~m}$ & $\mathrm{~d}=1,2 \mathrm{~m}$ & $\mathrm{~d}=1$ & $\mathrm{~d}=0,8$ \\
\hline $1,5 \mathrm{~m}$ & $99 \%$ & $76,6 \%$ & $55,8 \%$ & $42,6 \%$ & $28,5 \%$ & $3,3 \%$ & $0,4 \%$ \\
\hline $2 \mathrm{~m}$ & $99,7 \%$ & $83,2 \%$ & $63 \%$ & $48,9 \%$ & $33,6 \%$ & $4 \%$ & $0,5 \%$ \\
\hline $2,5 \mathrm{~m}$ & $99,9 \%$ & $87,5 \%$ & $68,3 \%$ & $54,1 \%$ & $38 \%$ & $4,7 \%$ & $0,6 \%$ \\
\hline
\end{tabular}

\section{CONCLUSION}

Knowing the results obtained from the research, it is concluded that the appropriate infiltration well model to be applied in the Sriwijaya State Polytechnic Campus is a cylindrical cross-sectional type with an impermeable wall with a depth of $1.5-2.5 \mathrm{~m}$ and a diameter of $1.4 \mathrm{~m}$ for every $100 \mathrm{~m}^{2}$ of rainfed area. The total number of infiltration wells required for a rainfed area of $26,177 \mathrm{~m}^{2}$ is 262 units. This infiltration well model has the highest effectiveness in controlling rain runoff, namely $(55.8 \%$ $63.3 \%$ ), and has the least overflow. However, the ability of infiltration wells to absorb water is low, $3.42 \mathrm{~cm} /$ hour or about $0.821 \mathrm{~m} /$ day. This value was found based on the results of measurements in the field using a double-ring infiltrometer.

\section{ACKNOWLEDGMENT}

This research was supported by State Polytechnic of Sriwijaya, Indonesia. The authors thank our colleagues who provided insight and expertise that greatly assisted the research.

\section{REFERENCES}

[1] NS Anggi, Pranoto R, Suryan V. 2020. Flood Hydrograph Calculation with Unit Hydrograph Method SCS (Soil Conservation Service) Synthesis in Palembang City. Journal of Airport Engineering Technology. 1(1): 1-7.

[2] Mohamadi MA and A Kavian. 2015. Effects of rainfall patterns on runoff and soil erosion in field plots. Journal of International Soil and Water Conservation Research. 3. (4): 273-281. https://doi.org/10.1016/j.iswcr.2015.10.001

[3]. Zhang Z, Xu W, Li L, Huang J, Deng L, \& Wang Q. 2021. Effects of temporal conservation measures on water erosion processes of disturbed soil accumulation in construction projects. Journal of Cleaner Production. 319. 128612. DOI: https://doi.org/10.1016/j.jclepro.2021.128612.

[4]. Chen H, Zhang X, Abla M, , Du Lü, Yana R, Rena Q, Ren Z, Yang Y, Zhao W, Pengfei Lin, Baoyuan
Liu, Xihua Yang. 2020. Effects of vegetation and rainfall types on surface runoff and soil erosion on steep slopes on the Loess Plateau, China. Catena. 170: 141-149. DOI: https://doi.org/10.1016/j.catena.2018.06.006

[5] Kumar R, Thaman S, Agrawal G, dan Poonam S. 2013. Rain water harvesting and ground water recharging in North Western Himalayan Region for Sustainable Agricultural Productivity. Journal of Environmental Research and Technology. 1(4): 539544.

[6] Afolayan SO, Makinde AA, Shuaib M, Idris BA, Yaduma JJ, dan Yau MG. 2012. Rainfall harvesting, a sustainable water management alternative for food security in Nigeria. Journal of Agricultural Research and Management. (136):1-8.

[7] Otti VI, dan Ezenwaji EE. 2013. Enhancing community-driven initiative in Rainwater Harvesting in Nigeria. International journal of Engineering and Technology. 3(1):73-79.

[8] Michelle NG and Yunita Ismail. 2020. Study of Rainwater Harvesting Implementation. Scientific Journal on Research and Application of Industrial System. 5(1): 37-47.

[9] Rupesh Devale, Thool Kushal P, Seema Jagtap. 2017. Conservation Strategies Using Watershed Management and Rainwater Harvesting. International Journal of Engineering and Applied Sciences (IJEAS). 4 (10): 76-82.

[10] Pinhati FSC, Rodrigues LN, Souza SA. 2020. Modelling the impact of on-farm reservoirs on dry season water availability in an agricultural catchment area of the Brazilian savannah. Agricultural Water Management. Volume 241, 1 November 2020. DOI:

[11] Mohajit. 2015. Mathematical Modelling of Injection Wells for Flooding Prevention in Jakarta. Procedia Engineering. 125: 207-212. DOI: https://doi.org/10.1016/j.proeng.2015.11.030

[12] Lia J, Chen JJ, Zhanc H, Guang Lid M, Xiae XH. 2020. Aquifer recharge using a partially penetrating well with clogging-induced permeability reduction. Journal of Hydrology. Volume 590. November 2020. DOI: https://doi.org/10.1016/j.jhydrol.2020.125391 
[13] [BSN] Badan Standardisasi Nasional. 2012. Standar Nasional Indonesia Nomor SNI-7752-2012 tentang Tata Cara Pengukuran Laju Infiltrasi. Jakarta. Indonesia.

[14] Minister of Public Works. 2014. Peraturan Menteri Pekerjaan Umum Republik Indonesia. Nomor 12 /PRT/M/2014 tentang Pengelolaan Air Hujan pada Bangunan Gedung dan Persilnya. Jakarta. Indonesia.

[15] [BSN] Badan Standardisasi Nasional. 2002. Standar Nasional Indonesia Nomor 03-2453-2002 tentang Tata Cara Perencanaan Sumur Resapan Air Hujan Untuk Lahan Pekarangan. Jakarta (ID): BSN.

[16] NC Olson, JS Gulliver, JL Nieber, and M Kayhanian. 2013. Remediation to improve infiltration into compact soils. Journal of Environ Manage. 117. pp. 85-95.

[17]. Rebecca L. Anderson, Kristofor R. Brye, Lisa S. Wood. 2020. Landuse and soil property effects on infiltration into Alfisols in the Lower Mississippi River Valley, USA. Geoderma Regional. Volume 22. e00297. https://doi.org/10.1016/j.geodrs.2020.e00297

[18]. Lukáš Jačka, Alena Walmsley, Martin Kovář, Jan Frouz. 2021. Effects of different tree species on infiltration and preferential flow in soils developing at a clayey spoil heap. Geoderma. Volume 403, 1 December 2021, 115372 . DOI: https://doi.org/10.1016/j.geoderma.2021.115372.

[19] SJE Van Dijck and Th. WJ Van Asch. 2002. Compaction of loamy soils due to tractor traffic in vineyards and orchards and its effect on infiltration in southern France. Soil and Tillage Research. 63. (34): 141-153.

[20]. Johnson T, Cameron D, Moore G, \& Brien C. 2020. Ground movement in a moderately expansive soil subject to rainfall infiltration through pervious paving. Ecological Engineering. 158. 106022. DOI: https://doi.org/10.1016/j.ecoleng.2020.106022

[21]. Zhang L, Wang J, Bai Z, Lv Chunjuan. 2015. Effects of vegetation on runoff and soil erosion on reclaimed land in an opencast coal-mine dump in a loess area. Catena. 128. 44-53.

[22]. Akter T, Quevauviller P, Eisenreich SJ, Vaes G. 2018. Impacts of climate and land use changes on flood risk management for the Schijn River, Belgium. Environmental Science \& Policy. 89: 163175. https://doi.org/10.1016/j.envsci.2018.07.002.

[23] Lee R. 1990. Hidrologi Hutan. Yogyakarta: Gadjah Mada University Press.

[24] Ahmed SM, Khamis NS, Ammar HK. 2020.

Modeling of Runoff in the Arid Regions Using Remote Sensing and Geographic Information System
(GIS). International Journal of Design \& Nature and Ecodynamics. 15 (5): 691-700.

[25] Selma YK. 2018. Effects of the land use/cover on the surface runoff and soil loss in the Niğde-Akkaya Dam Watershed, Turkey. Journal of Catena. 163: 233-243.

[26]. Owuor SO, Butterbach-Bahl K, Guzha AC, Rufino MC, Pelster DE, Pines ED, Breuer L. 2016. Groundwater recharge rates and surface runoff response to land use and land cover changes in semiarid environments. Ecol Process. 5. 16. https://doi.org/10.1186/s13717-016-0060-6.

[27]. Alavinia M, Saleh FN, \& Asadi H. 2018. Effects of rainfall patterns on runoff and rainfall-induced erosion. International Journal of Sediment Research. 34. (3): 270-278.

[28]. Deng L, Sun T, Fei K, Zhang L, Fan X, Wu Y, \& Ni L. 2019. Effects of erosion degree, rainfall intensity and slope gradient on runoff and sediment yield for the bare soils from the weathered granite slopes of SE China. Geomorphology. 352. 106997. DOI: https://doi.org/10.1016/j.geomorph.2019.106997.

[29] Ronalton EM, Tais OC, dan Matheus HM. 2021. Determination of Runoff Coefficient (C) In Catchments Based On Analysis Of Precipitation And

Flow Events. International Soil and Water Conservation Research Journal. https://doi.org/10.1016/j.iswcr.2021.09.001

[30] Sunyoto. 1988. Optimasi Sumur Resapan Sebagai Salah Satu Pencegahan Intrusi Air Laut. Makalah Seminar. Jogjakarta: PAU-IT Universitas Gadjahmada.

[31] Z Zhiqiang, W Zijian, W Sheping, D Yanping, Y Zhiming, Jinsuo Lu. 2021. Improvement of rainwater infiltration and storage capacity by an enhanced seepage well: From laboratory investigation to HYDRUS-2D numerical analysis. Journal of Hydroenvironment Research. 39: 15-24.

[32]. Grau-Martínez A, Folch A, Torrentó C, Valhondo C, Barba C, Domènech C, Soler A, Otero N. 2018. Monitoring Induced Denitrification During Managed Aquifer Recharge in an Infiltration Pond. Journal of Hydrology.

DOI: https://doi.org/10.1016/j.jhydrol.2018.03.044.

[33]. Hossain MI, Bari MN, Miah SU, Kafy AA, and Nasher NMR. 2021. Application of modified managed aquifer recharge model for groundwater management in drought-prone water-stressed Barind Tract, Bangladesh. Environmental Challenges. 4. 100173

DOI: https://doi.org/10.1016/j.envc.2021.100173. 